\title{
Model Capacity Building Pada Pesantren Perbatasan Binaan Dinas Pendidikan Dayah Provinsi Aceh
}

\author{
Muhammad Anggung Manumanoso Prasetyo, Bashori, Masriani \\ Institut Agama Islam Negeri Lhokseumawe, Indonesia \\ UIN Imam Bonjol Padang, Indonesia \\ STAI Auliaurrasyidin Tembilahan, Indonesia \\ anggung.679@iainlhokseumawe.ac.id, bashoribashori@gmail.com, masriani@gmail.com
}

\begin{abstract}
The era of globalization demands education institution to be adaptive, creative, and innovative, including Islamic boarding schools as the institutions of Islamic education which become the national cultural heritage. One of the innovative programs is capacity building as a series of strategies aimed at increasing efficiency, effectiveness, and responsiveness of performance. This study was directed to explore capacity building implementation at Darul Amin Islamic modern boarding school Southeast Aceh. A qualitative research approach with a case study as the research strategy was implemented. The results of the study showed that capacity building focused on three dimensions, namely (1) buman resource development; (2) organizational strengthening, and (3) institutional reform. The principle of Darul Amin capacity building contained the elements of participation, repetition, relevance, transfer, and feedback. In the process of capacity building, there were four stages, namely (1) preformal stage (pilot education organization); (2) formal stage (potential education organization); (3) transitional stage (national standard education organization); and (4) autonomous stage (international standard education organization). Towards the existence of the institution, Darul Amin also made various efforts at various levels, namely the system level, organizational level, and individual level.
\end{abstract}

Kata Kunci: Capacity Building, Organization, Dayah, Islamic Boarding School.

\begin{abstract}
Abstrak
Era globalisasi menuntut lembaga pendidikan adaptif, kreatif dan inovatif, termasuk pesantren sebagai lembaga pendidikan Islam warisan budaya bangsa. Program inovatif salab satunya adalah pengembangan kapasitas (capacity building) sebagai serangkaian strategi yang ditujukan untuk meningkatkan efisiensi, efektifitas, dan responsifitas dari kinerja. Penelitian ini bertujuan untuk mengeksplorasi capacity building pada organisasi pesantren. Metode yang digunakan oleb penelitian ini adalab kualitatif dengan pendekatan analisis deskriptif. Penelitian dilakukan di Pesantren Perbatasan Aceb Tenggara sebagai salab satu pesantren binaan Dinas Pendidikan Dayah Provinsi Aceh. Hasil penelitian menunjukan untuk capacity building memusatkan perhatian kepada 3 dimensi yaitu (1) pengembangan sumber daya manusia; (2) penguatan organisasi, dan (3) reformasi kelembagaan. Prinsip capacity building Dayah Perbatasan Darul Amin mengandung unsur partisipasi, pengulangan, relevansi, pengalihan, dan umpan balik. Dalam proses capacity building terdiri dari empat tahapan yaitu tahap (1) pra-formal (organisasipendidikan rintisan); (2) tahap formal (organisasi pendidikan potensi); (3) tahap transisional (organisasi pendidikan standar nasional); dan (4) tabap otonom (organisasi pendidikan standar internasional). Menuju kepada eksistensi kelembagaan Darul Amin juga melakukan berbagai upaya dalam berbagai tingkatan yaitu tingkatan sistem, tingkatan organisasi dan tingkatan individual.
\end{abstract}

Kata Kunci: Capacity Building, Organisasi, Dayah, Pesantren.

Permalink/DOI: https://doi.org/10.18326/infs13.v14i1.71-96 


\section{Pendahuluan}

Masyarakat pada umumnya memilih lembaga pendidikan yang sudah teruji kualitasnya, hanya sebagian kecil yang berani berspekulasi untuk menyekolahkan anaknya pada lembaga pendidikan rintisan. Kompleksitas tantangan terhadap dunia pendidikan menuntut organisasi pendidikan untuk melakukan serangkaian inovasi. Salah satu kegiatan yang bersifat inovatif dalam pengembangan lembaga pendidikan adalah capacity building atau pegembangan kapasitas kelembagaan.

Darul Amin sebagai pesantren milik pemerintah Aceh senantiasa berupaya meningkatkan mutu penyelenggaraan pendidikan dan pengajaran. Agar lebih kompetitif sekaligus sebagai bentuk penjaminan kualitas penyelengaraan, Darul Amin melakukan peningkatan kapasias kelembagaan (Mukhtar, et. al., 2020). Hal tersebut sesuai dengan Renstra yang disusun Dinas Pendidikan Dayah, bahwa pesantren perbatasan berorientasi menjadi pesantren berstandar internasional (Dinas Pendidikan Dayah Aceh, 2019).

Sebagaimana penelitian yang dilakukan Murray (2009), Spoth, Bierman, Redmond (2004) bahwa pengembangan kapasitas (capacity building) kelembagaan merupakan alternatif solusi dari serangkaian kegiatan berbasis peningkatan mutu. Konsep ini juga mampu menjadikan lembaga pendidikan termasuk pesantren mampu mempertahankan eksistensinya di tengah masyarakat (O’Brien et al., 2013).

Hollis Chenery dalam Veithzal lewat tulisannya berjudul "Industralization and Growth" memaparkan sejarah pembangunan manusia sejak tahun 1970, 40\% pembangunan ekonominya ditentukan oleh tingginya tingkat produktivitas penduduknya yang dibangun melalui pendidikan. Dibuktikan bahwa rata-rata sumbangan produktivitas masyarakat negara-negara kaya sebesar 49\%, negara komunis 35\% dan negara berkembang 31\%. Selain itu, negara-negara yang angkatan kerjanya relatif panjang ditandai oleh kebijakan untuk memberi porsi serius terhadap pembangunan manusia (Rivai, et. al., 2014).

Veitzal Rivai menjelaskan dalam pengembangan kapasitas 
individu, kelompok dan organisasi bukan hanya sekedar mentransfer pengetahuan, keterampilan, atau sikap akan tetapi berbagi dengan mereka. Pengembangan kapasitas tidak mengubah kemampuan tetapi hanya menambah atau mengganti kemampuan yang sudah ada (Rivai \& Murni, 2009).

Sedangkan peningkatan kapasitas berdasarkan UNDP (United Nations Development Program) dan CIDA (Canadian International Development Agency) dalam Milen adalah proses dimana masyarakat, individu, kelompok, organisasi, dan institusi dalam meningkatkan kemampuan mereka untuk (a) menghasilkan kinerja pelaksanaan tugas pokok dan fungsi (corefunctions), memecahkan permasalahan, merumuskan dan mewujudkan pencapaian tujuan yang telah ditetapkan, dan (b) memahami dan memenuhi kebutuhan pembangunan dalam konteks yang lebih luas dalam cara yang berkelanjutan (Human Development Report, 2019).

Hal ini sejalan dengan konsep pengembangan kapasitas menurut Grindle yang menyatakan bahwa pengembangan kapasitas sebagai ability to perform appropriate task effectvely, efficiently and sustainable. Bahkan Grindle menyebutkan bahwa pengembangan kapasitas mengacu kepada improvement in the ability of public sector organizations (Grindle, 2007). Kajian penelitian yang berkaitan dengan tema capacity building dalam konteks organisasi pendidikan juga pernah dilakukan oleh Ho (2019), Galamba, Kirsten, Nielsen (2019), (Karunasena, 2007) yang bersama menyatakan bahwa capacity building berpengaruh terhadap mutu penyelenggaraan pendidikan khususnya bagi peningkatan kapasitas guru dalam proses pembelajaran dan tingkat kemandirian ekonomi pesantren.

Penelitian ini bertujuan membantu mempromosikan pemahaman tentang atribut, praktik, dan tema yang terkait dengan peningkatan kapasitas untuk peningkatan pesantren. Peningkatan pesantren di tingkat praktik dimana para stakeholder membuat dan mempertahankan proses perbaikan. Adapun analisis pembahasan berkaitan dengan (1) pengembangan kapasitas yang tertanam dalam konteks perubahan eksternal (makro) dan internal (mikro), atribut dan praktik yang mendukung fenomena tersebut; dan atribut, praktik, dan tema yang muncul yang berkontribusi pada model 
pengembangan kapasitas untuk peningkatan pesantren.

\section{Landasan Teori}

Konsepsi Capacity Building

Secara terminologi, kapasitas berasal dari bahasa Belanda; capacitiet yang berarti tiga hal pertama yakni daya tampung atau daya serap, kedua ruang atau fasilitas yang tersedia, dan terakhir kemampuan maksimal. Pengertian pengembangan kapasitas secara terminologi masih mengalami perbedaan pendapat, ada beberapa yang merujuk pada pengertian dalam konteks kemampuan (pengetahuan, keterampilan, dan lain lain), dan sebagian lain mengartikan dalam konteks yang lebih luas, termasuk di dalamnya terdapat sikap dan perilaku. Sebagian ilmuwan juga melihat pengembangan kapasitas sebagai capacity development atau capacity strengthening, mengisyaratkan suatu prakarsa pada pengembangan kemampuan yang sudah ada (existing capacity) (Had $\square$ eld, Chapman, Curryer, \& Barrett, 2004).

Sementara yang lain lebih merujuk pada constructing capacity sebagai proses kreatif membangun kapasitas yang belum nampak. Stringer memberikan pengertian "Capacity building is a process that increases the ability of persons, organisations or system to meet its stated purposes and objectives". Dari pengertian tersebut dapat dimaknai bahwa pengembangan kapasitas adalah suatu proses yang dapat meningkatkan kemampuan seseorang organisasi atau sistem untuk mencapai tujuan yang hendak dicapai (Stringer, 2013).

Sedangkan menurut Soeprapto pengertian pengembangan kapasitas, mencangkup beberapa poin penting yaitu (Riyadi, 2010) yaitu (1) pengembangan kapasitas bukanlah produk, melainkan sebuah proses; (2) pengembangan kapasitas adalah proses pembelajaran multi-tingkatan meliputi individu, grup, organisasi, dan sistem; (3) pengembangan kapasitas menghubungkan ide terhadap sikap; (4) pengembangan kapasitas dapat disebut sebagai contoh actionable learning dimana pengembangan kapasitas meliputi sejumlah proses-proses pembelajaran yang saling berkaitan, akumulasi benturan yang menambah prospek untuk individu dan organisasi agar secara terus-menerus beradaptasi atas perubahan.

Keban (1999) mendefinisikan pengembangan kapasitas 
(capacity building) sebagai serangkaian strategi yang ditujukan untuk meningkatkan efisiensi, efektifitas, dan responsifitas dari kinerja. Lebih lanjut Morrison (2001) menyatakan bahwa "Learning is a process, which flows from the need to make sense out of experience, reduce the unknown and uncertain dimensions of life and build the competencies required to adapt to change". Dari penjelasan diatas dapat dipahami bahwa tujuan dari Capacity Building (pengembangan kapasitas) adalah pembelajaran, berawal dari mengalirnya kebutuhan untuk mengalami suatu hal, mengurangi ketidaktahuan dan ketidakpasitian dalam hidup, dan mengembangkan kemampuan yang dibutuhkan untuk beradaptasi menghadapi perubahan.

Alma dan Lambert (2006) memaknai capacity building sebagai sebuah usaha menciptakan peluang melalui masyarakat organisasi untuk bekerja bersama-sama dengan cara baru yang lebih integratif. Capacity building juga sangat mempengaruhi perkembangan sekolah. Sergiovanni, Hopkins dan Jackson dalam Alma menyatakan bahwa diantara yang berperan penting dalam pembangunan kapasitas adalah kepemimpinan, anggota, profesionalisme, dan dukungan murid. Capacity building merupakan pengembangan dari konsep manajemen perubahan (Bashori et. al., 2020).

Pengertian capacity building menurut pendapat Fullan dalam Stoll merupakan upaya pengembangan internal dengan dukungan eksternal sebagai strategi meningkatkan efisiensi, efektivitas dan responsivitas kinerja organisasi (Stoll, 2009), yakni efisiensi, dalam hal waktu (time) dan sumber daya (resources) yang dibutuhkan guna mencapai suatu outcomes; efekfivitas berupa kepantasan usaha yang dilakukan demi hasil yang diinginkan; dan responsivitas merujuk kepada bagaimana mensikronkan antara kebutuhan dan kemampuan untuk maksud tersebut.

Dimensi, fokus dan tipe kegiatan tersebut menurut Grindle (2007) adalah: (1) dimensi pengembangan SDM, dengan fokus: personil yang profesional dan kemampuan teknis serta tipe kegiatan seperti: pendidikan dan pelatihan (diklat), praktek langsung, kondisi iklim kerja, dan rekruitmen; (2) Dimensi penguatan organisasi, dengan fokus: tata manajemen untuk meningkatkan 
keberhasilan peran dan fungsi, serta tipe kegiatan seperti: sistem insentif, perlengkapan personil, kepemimpinan, budaya organisasi, komunikasi, struktur manajerial; dan (3) Reformasi kelembagaan, dengan fokus: kelembagaan dan sistem serta makro struktur, dengan tipe kegiatan: aturan main ekonomi dan politik, perubahan kebijakan dan regulasi, dan reformasi konstitusi.

Sejalan dengan definisi yang dipaparkan di atas, Hardjanto memberikan kesamaan pengertian yang digolongkan dalam 3 aspek berikut ini: (1) pengembangan kapasitas merupakan suatu proses; (2) pelaksanaan proses tersebut dilaksanakan pada tiga level/tingkatan, yaitu individu, kelompok dan institusi atau organisasi, dan (3) dan tujuan proses tersebut adalah untuk menjamin kesinambungan organisasi melalui pencapaian tujuan dan sasaran organisasi yang bersangkutan (Harjanto, 2006).

Tim Peneliti STIA LAN Makasar dalam penelitiannya menyebutkan bahwa capacity building merupakan serangkaian strategi untuk peningkatan efisiensi, efektivitas dan responsivitas (Tim Peneliti STIA LAN, 2012). Capacity Building bukan proses yang berangkat dari nol atau ketiadaan, melainkan berawal dari membangun potensi yang sudah ada untuk kemudian diproses agar lebih meningkat kualitas diri, kelompok, organisasi serta sistem agar tetap dapat beratahan di tengah lingkungan yang mengalami perubahan secara terus-menerus. Pengembangan kapasitas yang dimaksud dalam penelitian ini adalah pengembangan kapasitas kelembagaan organisasi pesantren.

\section{Tujuan Capacity Building}

Program ini bertujuan untuk meningkatkan kemampuan setiap satuan pendidikan secara berkelanjutan baik untuk melaksanakan peran. Peran yang dimaksud dalam aspek manajemen pendidikan maupun pembelajaran. Berdasarkan pendapat ahli di atas menunjukkan bahwa tujuan capacity building dapat dibagi menjadi 2 bagian yaitu: (1) secara umum diidentikkan pada perwujudan sustainabilitas (keberlanjutan) suatu sistem; dan (2) secara khusus ditujukan untuk mewujudkan kinerja yang lebih baik dilihat dari beberapa aspek, diantaranya (a) efisiensi dalam hal waktu (time) dan sumber daya (resources) yang dibutuhkan guna mencapai suatu 
outcome; (b) efektivitas berupa kepantasan usaha yang di lakukan demi hasil yang diinginkan; (c) responsivitas yaitu bagaimana mensinkronkan antara kebutuhan dan kemampuan untuk maksud tersebut; dan (c) pembelajaran yang terindikasi pada kinerja individu, grup, organisasi dan sistem.

Karakteristik pengembangan kapasitas yaitu: (1) merupakan sebuah proses yang berkelanjutan; (2) memiliki esesensi sebagai sebuah proses internal; (3) dibangun dari potensi yang telah ada; (4) memiliki nilai intrinsik tersendiri; (5) mengurus masalah perubahan; (6) menggunakan pendekatan terintegrasi dan holistik (Gandara, 2008).

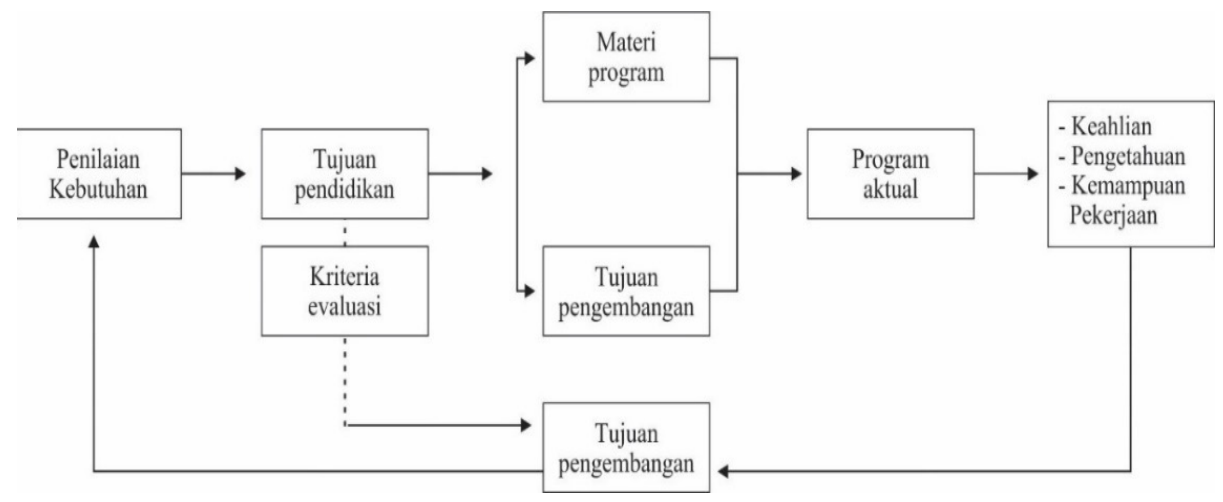

Gambar 1. Model Konseptual Pembangunan Kapasitas (Capacity Building) Sumber: Veithzal Rivai dan Sylviana (2009).

Pada gambar 1 tersebut di atas, bentuk pengembangan kapasitas dapat diawali dari penilaian kebutuhan adalah diagnosa untuk menentukan masalah saat ini dan tantangan masa depan. Tujuan pendidikan harus dapat memenuhi kebutuhan yang diinginkan oleh lembaga serta dapat membentuk tingkah laku yang diharapkan. Materi program disusun dari estimasi kebutuhan dan tujuan pengembangan. Prinsip pembelajaran, akan berjalan efektif jika metode disesuaikan dengan jenis pekerjaan yang dibutuhkan organisasi. Prinsip ini mengandung unsur partisipasi, pengulangan, relevansi, pengalihan, dan umpan balik.

Variabel konstruk yang dibangun dalam penelitian ini terkait variabel Capacity Building yaitu serangkaian strategi berupa pengembangan yang dialami oleh individu, kelompok 
dan organisasi untuk untuk peningkatan efisiensi, efektivitas dan responsivitas terhadap perubahan (Matachi, 2006). Dimensi, fokus dan tipe kegiatan tersebut yaitu: (1) dimensi pengembangan SDM, dengan fokus: personil yang profesional dan kemampuan teknis serta tipe kegiatan seperti pendidikan dan pelatihan (diklat), praktek langsung, kondisi iklim kerja, dan rekruitmen; (2) dimensi penguatan organisasi, dengan fokus pada tata manajemen untuk meningkatkan keberhasilan peran dan fungsi, serta tipe kegiatan seperti sistem insentif, perlengkapan personil, kepemimpinan, budaya organisasi, komunikasi, struktur manajerial, dan (3) reformasi kelembagaan, dengan fokus kelembagaan dan sistem serta makro struktur, tipe kegiatan berupa aturan main ekonomi dan politik, perubahan kebijakan dan regulasi, dan reformasi konstitusi (Ku \& Yuen-Tsang, 2011).

\section{Metode Penelitian}

Paradigma penelitian ini adalah kualitatif dengan metode analisis deskriptif. Informan dalam penelitian ini adalah pimpinan, guru dan karyawan pesantren. Penentuan informan menggunakan model snowball exponential discriminative atau rantai rujukan (Y. S. Lincoln \& Guba, 2003). Metode pengumpulan data sekaligus strategi analisis data menggunakan metode observasi, wawancara dan dokumentasi, dengan kata lain prosedur metodis sekaligus juga adalah strategi analisis data itu sendiri (Cresswell, 2008), (Bungin, 2018). Bertindak sebagai informan dalam penelitian ini adalah pegawai struktural di Dinas Dayah Aceh, Pimpinan pesantren, dewan guru dan koordinator pelaksana kegiatan. Uji keabsahan data dilakukan dengan metode triangulasi data dan teori (Moleong, 2011).

\section{Hasil dan Pembahasan}

\section{Profil Dayah Perbatasan Darul Amin}

Dayah Perbatasan Darul Amin (DPDA) didirikan oleh Yayasan Darul Amin pada tahun 1998. Bertindak sebagai ketua Yayasan aktif saat ini adalah Bupati Aceh Tenggara Ir. H. Hasanuddin B, MM. Pada awal mula berdirinya Darul Amin bernama Pesantren Modern Terpadu Darul Amin seiring dengan jenjang pendidikan formal yang diterapkan yaitu SMP dan SMK. Sejak 10 tahun berdiri 
Darul Amin belum menerapkan system pendidikan pesantren murni (boarding school) bagi para santrinya, baru kemudian di awal tahun 2008 DPDA menerapkan system pesantren modern yang kurikulum pendidikan dan pengajarannya mengacu kepada pondok modern Darussalam Gontor. Seiring meningkatnya kualitas dan kuantitas DPDA pada Tahun 2010 perhatian kepada DPDA semakin meningkat hal ini dibuktikan dengan perubahan Darul Amin menjadi Dayah Perbatasan Darul Amin sekaligus menjadi salah satu dari empat pesantren se-Aceh yang dibina langsung oleh Badan Pembinaan Pendidikan Dayah (https://dpd.acehprov.go.id/, 2019).

Berdasarkan hasil dokumentasi, pada awal penerimaan Tahun Ajaran 2019-2020 ini Darul Amin memiiki jumlah santri sebanyak 620 santri dengan daerah asal santri yang luas mulai luar kabupaten Aceh Tenggara, dan luar provinsi seperti Medan, Padang Lawas, Pekanbaru, dan Lampung (www.dayahperbatasandarulamin. ac.id, 2019). Sejak berstatus pesantren binaan pemerintah, saat ini pesantren memiliki alumni sebanyak 210 santri dan tersebar hingga kemanca negara. Hal tersebut sebagai cerminan tujuan Darul Amin sebagai Pesantren Perbatasan Bertaraf Internasional.

\section{Capacity Building di Dayah Perbatasan Darul Amin}

Sebelum dilakukan pengembangan Dayah Perbatasan Darul Amin berusaha memenuhi beberapa aspek dasar terkait kelembagaan. Pemenuhan aspek dasar kelembagaan tersebut diwujudkan mengikuti teori struktur organisasi organisasi mencangkup beberapa aspek sebagaimana tersaji pada gambar 2 berikut ini. 


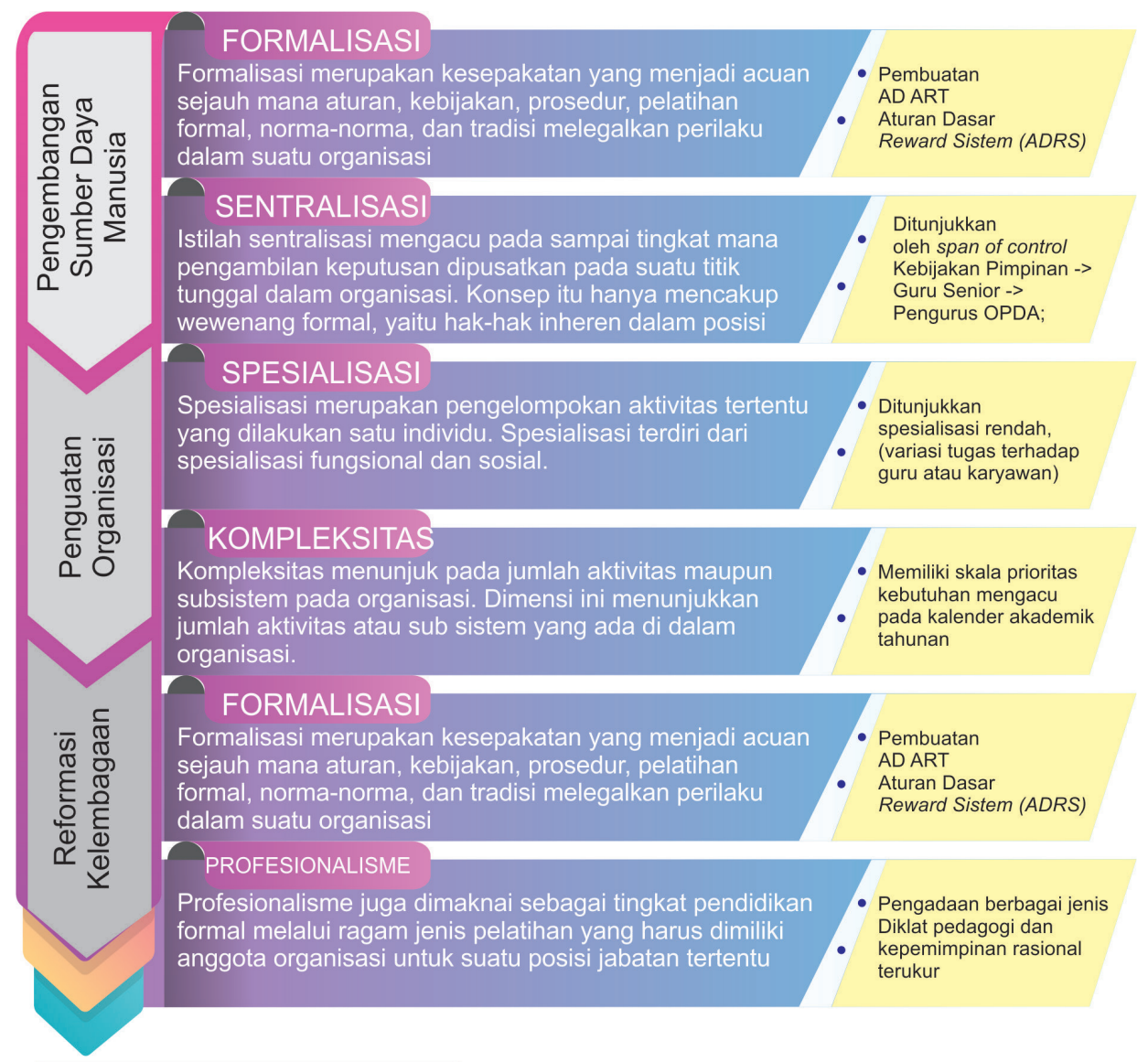

Pemenuhan Aspek Capacity Building

Gambar 2. Pemenuhan Aspek Capacity Building melalui Struktur

Organisasi

Untuk itu pengembangan kapasitas memusatkan perhatian kepada 3 dimensi yaitu (1) pengembangan sumber daya manusia; (2) penguatan organisasi, dan (3) reformasi kelembagaan. Pengembangan SDM yang dilakukan Dayah Perbatasan Darul Amin antara lain pada tahun 2013 bekerja sama dengan Pesantren Gontor sebagai pioneer sistem pesantren modern yang disebut Mu'allimin dalam beberapa hal. Pertama, guru pengabdian baik putra maupun putri sebagai manajer operasional lapangan yang menanggungjawabi aktivitas kegiatan santri mulai dari ekstrakurikuler seperti kepramukaan hingga penanaman kecakapan hidup lifeskill santri. 
Kedua, mendatangkan guru senior tamatan Universitas Darussalam Gontor (UNIDA) untuk ditempatkan pada posisi strategis, yaitu pengasuhan santri, administrasi dan kesekretariatan. Selain itu pos tenaga kependidikan juga mulai terpenuhi mulai satpam, cleaning service, juru masak hingga karyawan unit usaha.

Kedua, penguatan organisasi dilakukan mulai tahun 2010, langkah awal yang dilakukan adalah penguatan ekonomi pesantren dengan target Darul Amin mandiri dalam 10 tahun ke depan. Berbagai unit usaha mulai didirikan hingga tahun 2019 Darul Amin sudah memiliki unit produksi yang membuat kursi dan meja belajar santri. Penguatan organisasi lewat kemandirian ekonomi terbukti efektif, karena dalam lima tahun terakhir Darul Amin secara mandiri mampu membangun berbagai sarana dan fasilitas seperti, kolam ikan untuk usaha perikanan, air RO untuk minum santri, lapangan sepakbola, perluasan kanopi kantor pusat, guest house, pos satpam, drainase, taman sekitar pesantren dan lain sebagainya. Tercatat biaya yang dikeluarkan selama 5 tahun mulai 2014 hingga 2018 mencapai 1,2 M, sedangkan 400 juta digunakan untuk pemerataan lahan. Ketiga, Reformasi kelembagaan di Dayah Perbatasan Darul Amin dimulai sejak tahun 2010 adalah proses peralihan status menjadi pesantren perbatasan atau dayah perbatasan. Muchlisin dan Arifin, (terwawancara), (2019). Kemudian perubahan jenjang pendidikan formal dari SMK menjadi Madrasah Aliyah. Tabel 1 berikut ini memaparkan tentang dimensi pengembangan kelembagaan Darul Amin (Wahyudi, (terwawancara) (2019).

Tabel 1: Dimensi Capacity Building Darul Amin

\section{Dimensi Program dan Sasaran}

\begin{tabular}{lll}
\hline Pengembangan & Rekrutmen guru senior untuk ditempatkan \\
SDM & pada posisi strategis pengasuhan santri dan \\
& ADM kesekretariatan; \\
- & Rekrutmen guru pengabdian sebagai manajer \\
& operasional lapangan menangani kegiatan \\
& ekstrakurikuler dan penanaman lifeskill santri;
\end{tabular}


Penguatan

Organisasi

Reformasi

Kelembagaan
- Penguatan unit usaha pesantren menuju pada kemandirian ekonomi;

- Penguatan relasi melalui pengadaan DIKLAT kompetensi manajerial dan akademik guru;

- Menjadi salah satu sekolah penerima program SMP Berbasis Pesantren

- Perubahan status kelembagaan menjadi binaan Dinas Pendidikan Pesantren Provinsi Aceh;

- Perubahan jenjang pendidikan formal SMK menjadi Madrasah Aliyah

\section{Sumber: Hasil Penelitian}

Bentuk capacity building dapat dijelaskan sebagaimana berikut: (1) penilaian kebutuhan adalah diagnosa untuk menentukan masalah saat ini dan tantangan masa depan; (2) tujuan pendidikan harus dapat memenuhi kebutuhan yang diinginkan oleh lembaga serta dapat membentuk tingkah laku yang diharapkan; (3) materi program disusun dari estimasi kebutuhan dan tujuan pengembangan; (4) prinsip pembelajaran, akan berjalan efektif jika metode disesuaikan dengan jenis pekerjaan yang dibutuhkan organisasi. Prinsip ini mengandung unsur partisipasi, pengulangan, relevansi, pengalihan, dan umpan balik.

Diagnosa atas kebutuhan sebagai tantangan masa depan adalah pesantren yang tertuang dalam rencana strategis lima tahunan pesantren. Tujuan pendidikan selaras dengan tujuan lembaga, yaitu prioritas program pendidikan dan pengajaran pesantren yang terintegratif implementatif manajemen berbasis pesantren muallinim. Arah pengembangan pesantren menuju kepada terbentuknya pesantren mandiri yang berdaya saing. Sedangkan untuk prinsip pembelajaran pesantren Darul Amin mengintegrasikan tiga kurikulum antara kurikulum mua'llimin (berbasis ilmu keagamaan), kurikulum kedinasan dan kurikulum khas daerah (dayah salafy) sesuai qanun pemerintahan Aceh;

Bentuk pengembangan pesantren mengandung unsur partisipasi karena melibatkan seluruh komponen mulai manajemen puncak yang diwakili oleh Dinas Pendidikan Dayah (pesantren) 
provinsi Aceh sebagai Pembina, manajemen tingkat menengah para pengelola pesantren dan manajemen operasional yang diwakili guru-guru di pesantren. Pengembangan ini juga mengandung prinsip pengulangan, dalam artian include ke dalam sistem yang berjalan pada proses pendidikan dan pengajaran. Adapun prinsip relevansi adalah tuntutan kebutuhan pesantren agar tetap eksis adalah melakukan serangkaian program inovatif yang dapat diterima oleh masyarakat. Sementara berkaitan dengan prinsip pengalihan, pesantren membangun relasi kerjasama dengan memanfaatkan gontor connection.

Progres kemajuan sebagai bentuk umpan balik terhadap usaha peningkatan kelembagaan dalam beberapa tahun terakhir diantaranya adalah pengembangan kapasitas yang dilihat melalui mata berbagai pemangku kepentingan sekolah: pimpinan pesantren; dewan guru; staf pelengkap terlibat langsung dalam upaya peningkatan. Dalam praktiknya, ini menentukan dan membuat rekomendasi tentang apa yang dapat dilakukan oleh pembuat kebijakan, pengembang reformasi dan pemangku kepentingan sekolah untuk meningkatkan pembangunan kapasitas.

\section{Faktor yang mempengarubi Capacity Building}

Capacity Building dapat diukur sesuai dengan tingkat pencapaiannya yang diinginkan, apakah diperuntukkan dalam jangka waktu yang pendek, menengah atau panjang. Proses Capacity Building dalam tingkatan yang terkecil merupakan proses yang berkaitan dengan pembelajaran dalam diri individu, kemudian pada tingkat kelompok, organisasi dan sistem dimana faktor-faktor tersebut juga difasilitasi oleh faktor eksternal yang merupakan lingkungan pembelajarannya. Dalam jangka waktu yang sangat panjang dan terus menerus, maka pengembangan kapasitas memerlukan aktifitas adaptif untuk meningkatkan kapasitas stakeholdernya. Pembentukan budaya organisasi yang kondusif sangat berpengaruh terhadap efektivitas pelaksanaan program (Cosner, 2009).

Faktor-faktor yang mempengaruhi pengembangan kapasitas adalah komitmen bersama (collective commitments); kepemimpinan transformasional; reformasi peraturan; dan reformasi kelembagaan. Adapun dalam konteks pengembangan kapasistas lembaga di Dayah 
Perbatasan Darul Amin melalui hasil penelitian dilaksanakan melalui empat hal. Pertama, komitmen bersama antara pejabat Dinas terkait yaitu kepada Dinas Pendidikan Dayah Aceh, Pimpinan Pesantren dan Guru-guru sebagai jajaran operasional di lapangan. Karena komitmen merupakan modal dasar yang terus ditumbuhkembangkan dan dipelihara secara baik, karena akan menjadi dasar dari seluruh rancangan kegiatan yang akan dilakukan oleh sebuah organisasi.

Kedua, dalam pelaksanaannya, Pimpinan pesantren memiliki tipe kepemimpinan transformasional. Indikator yang menunjukkan kepemimpinan transformasional yaitu pimpinan melakukan serangkaian program inovatif. Program tersebut memiliki resiko tetapi berdampak positif signifikan terhadap perkembangan pesantren. Sebagai contoh, pada tahun 2013 pimpinan gencar melakukan penghijauan dan perbaikan tata kelola pesantren. Hasilnya belum genap 5 tahun pada tahun 2017 dan 2018 Darul Amin berhasil menjadi pesantren Adiwiyata atau juara 1 provinsi pesantren terbersih dan tersehat di Provinsi Aceh. Kepemimpinan transformasional merupakan salah satu hal yang paling mendasar dalam mempengaruhi inisiasi dan kesuksesan program pengembangan kapasitas personal dalam kelembagaan sebuah organisasi. Dalam konteks lingkungan organisasi publik, harus terus menerus didorong sebuah mekanisme kepemimpinan yang dinamis.

Ketiga, kontekstualitas politik dan budaya pemerintahan di daerah yang selalu berlindung pada peraturan yang ada serta lain-lain faktor legal-formal prosedural merupakan hambatan yang paling serius dalam kesuksesan program pengembangan kapasitas. Hal tersebut mendorong Darul Amin melakukan serangkaian perubahan sistem demi menjaga stabilitas iklim kerja organisasi. salah satunya adalah menciptakan sistem penggajian melalui Aturan Dasar Reward Sistem (ADRS).

Keempat, reformasi kelembagaan pada intinya menunjuk kepada pengembangan iklim dan budaya yang kondusif bagi penyelenggaraan program kapasitas personal dan kelembagaan menuju pada realisasi tujuan yang ingin dicapai. Reformasi ini memiliki dua aspek penting yaitu struktural dan kultural. Kedua aspek ini menjadi aspek yang penting dan kondusif dalam 
menopang program. Karena pengembangan kapasitas harus diawali pada identifikasi, harus ada pengakuan dari personal dan lembaga tentang kelemahan dan kekuatan yang dimiliki dari kapasitas yang tersedia (existing capacities). Reformasi kelembagaan yang dirasakan Darul Amin, pada tahun 2010 Darul Amin resmi beralih status menjadi Dayah Perbatasan Darul Amin di bawah pemerintah Provinsi dalam binaan Badan Pembinaan Pendidikan Dayah (BPPD) yang pada tahun 2018 berubah menjadi Dinas Pendidikan Dayah (DPD) Provinsi Aceh. Selain itu, pada tahun 2009, Darul Amin juga mengalami reformasi jenjang pendidikan formal, Sekolah Menengah Kejuruan Swasta (SMKS) Darul Amin menjadi Madrasah Aliyah Swasta (MAS) Darul Amin.

\section{Tahapan Implementasi Capacity Building}

Kegiatan capacity building perlu dilakukan secara sistematis melalui beberapa tahap menjadi proses berkesinambungan sehingga arahnya menjadi jelas (straight foreward) dan terukur (measurable). Terdapat empat tahapan pokok yang perlu dilalui dalam pelaksanakan capacity building bagi setiap satuan pendidikan. Masing-masing tahap pengembangan dilakukan terhadap setiap kelompok satuan pendidikan yang memiliki karakteristik atau tahap perkembangan yang setara. Capacity building dilakukan untuk meningkatkan (upgrade) suatu kelompok satuan pendidikan dari tahap perkembangan tertentu ke tahap berikutnya. Keempat tahap perkembangan tersebut dapat dijelaskan pada gambar 3 berikut ini.

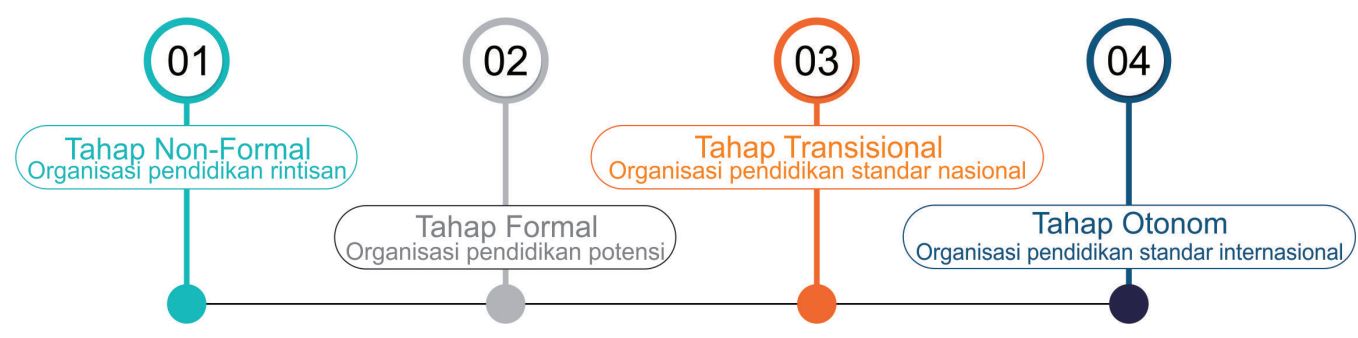

Gambar 3. Tahap implementasi capacity building. Tahap Pra-formal (organisasi pendidikan rintisan)

Satuan pendidikan yang termasuk kedalam kelompok ini adalah yang belum memenuhi standar teknis yaitu belum memiliki sumber- 
sumber pendidikan (misalnya guru, prasarana, sarana pendidikan, dan sebagainya) yang memadai untuk menyelenggarakan pelayanan pendidikan secara minimal. Akibat dari kurangnya sumber-sumber pendidikan satuan pendidikan ini belum memenuhi standar teknis sebagai persyaratan minimal satuan pendidikan yang siap untuk dikembangkan kemampuannya. Untuk dapat mulai dikembangkan kemampuannya, satuan-satuan pendidikan ini perlu dilengkapi fasilitas minimal pendidikannya terlebih dahulu agar dapat naik tahapan.

Pada tahap ini Darul Amin menghadapi problematika yang relatif sama dengan sekolah-sekolah rintisan. Darul Amin pada awal merintis hanya memiliki santri berjumlah 56 santri, selebihnya murid di sekolah formal berstatus ulang-alik. Sebagai rangkuman beberapa fenomena yang dihadapi Darul Amin pada fase rintisan adalah krisis identitas, dualisme Kepemimpinan, hegemoni sistem sekolah umum, dan minimnya gagasan.

\section{Tahap Formal (organisasi pendidikan potensi)}

Tahap ini merupakan tahap dimana Dayah Perbatasan Darul Amin sebagi salah satu satuan pendidikan termasuk ke dalam kelompok yang sudah memiliki sumber-sumber pendidikan yang memadai secara minimal. Darul Amin secara kelembagaan sudah mencapai standar teknis secara minimal, seperti dalam jumlah dan kualifikasi guru, jumlah dan kualitas ruang kelas, jumlah dan kualitas buku pelaj aran serta jumlah dan kualitas fasilitas pendidikan lainnya. Tahap ini berlangsung mulai tahun 2010 dimana Darul Amin mendapatkan bantuan fisik dalam partai besar. Bangunan fisik tersebut terdiri dari ruang kelas belajar (RKB), perumahan guru (asatidz), dapur santri, asrama santri yang kesemuanya berjumlah 17 bangunan. Selain itu, Darul Amin juga mendapat bantuan sarana seperti genset, alat-alat dapur, komputer dan lainnya sebagai sarana penunjang proses pendidikan dan pengajaran.

Pada tahap ini juga Darul Amin telah mencapai standar minimal teknis sehingga capacity building dapat dilakukan melalui peningkatan kemampuan administratur (seperti kepala sekolah) dan pelaksana pendidikan (seperti guru-guru, instruktur, tutor, dan sebagainya) agar dapat melaksanakan pengelolaan pendidikan 
secara efisien serta dapat menyelenggarakan proses pembelajaran yang kreatif dan inovatif. Jika pengembangan kemampuan ini sudah berhasil dilakukan, maka satuan-satuan pendidikan ini dapat ditingkatkan tahap perkembangan berikutnya, yaitu tahap transisional. Keberhasilan satuan pendidikan yang sudah mencapai tahap ini diukur dengan menggunakan standar pelayanan minimum tingkat sekolah, terutama yang menyangkut ukuran-ukuran output pendidikan seperti tingkat mutu lulusan, peningkatan hasil ujian nasional (UN), tingkat kemampuan akademik dan life skill para santri, kauntitas tingkat kelulusan, serta tingkat melanjutkan pendidikan tinggi.

\section{Tahap Transisional (organisasi pendidikan standar nasional)}

Organisasi pendidikan yang sudah mencapai tahap perkembangan ini adalah yang sudah mampu memberikan pelayanan minimal pendidikan yang bermutu, seperti kemampuan mendayagunakan sumber-sumber pendidikan secara optimal, meningkatnya kreativitas guru, pendayagunaan perpustakaan sekolah secara optimal, kemampuan untuk menambah anggaran dan dukungan fasilitas pendidikan dari sumber masyarakat, dan kemampuan lainnya yang mendukung best practices pelayanan pendidikan pada setiap satuan pendidikan. Dalam fase ini menurut proses perkembangan yang dialami Darul Amin dibagi ke dalam tiga tahap yaitu; tahap transisi; tahap stabilitasi; dan tahap eksistensi.

Pada tahap transisi yang menjadi prioritas adalah (1) rekrutmen SDM, dimulai dari kaderisasi guru ke jenjang pendidikan S2, Guru senior bidang pengasuhan santri, dan guru yang memenuhi kualifikasi akademik kesekretariatan; (2) rekrutmen Guru Pengabdian sebagai pelaksana kegiatan teknis operasional di lapangan seperti kegiatan ekstrakurikuler kepramukaan, pidato, praktek bahasa, olahraga dan lain sebagainya; (3) Otimalisasi organisasi santri darul amin (OPDA). Pada tahap stabilisasi, dimana Darul Amin sudah mulai melaksanakan sistem yang maksimal seperti (1) kegiatan berbasis kalender Akademik; (2) sistem evaluasi; (3) pengembangan kurikulum. Sedangkan pada tahap eksistensi mencangkup capaian berikut pengembangan jaringan, overseas study ke luar negeri, pengadaan diklat akademik, dan kaderisasi guru. Jika satuan-satuan pendidikan sudah mencapai tahap transisional selanjutnya dapat 
dinaikan ke tahap perkembangan berikutnya, yaitu tahap otonom. Tahap Otonom (organisasi pendidikan standar internasional)

Satuan pendidikan yang sudah mencapai tahap perkembangan ini dapat dikategorikan sebagai tahap penyelesaian capacity building menuju profesionalisasi satuan pendidikan menuju pelayanan pendidikan yang bermutu. Jika sudah mencapai tahap otonom, setiap satuan pendidikan sudah mampu memberikan pelayanan di atas standar pelayanan minimal (SPM) sekolah dan akan bertanggung jawab terhadap klien serta stakeholder pendidikan lainnya. Melihat perkembangan yang sudah berjalan, Darul Amin dapat dikatakan belum sepenuhnya mencapai tahap otonom. Apabila ditinjau dari beberapa aspek yang sudah memenuhi indikator otonom, salah satunya aspek output lulusan, saat ini tercatat lulusan Darul Amin sudah ada yang melanjutkan pendidikan ke perguruan tinggi luar negeri seperti Mesir dan Taiwan. Aspek lain yang masuk dalam kategori semi otonom adalah aspek kemandirian ekonomi. Hingga tahun 2018 Darul Amin sudah memiliki tujuh unit usaha seperti koperasi pelajar putra putri, kantin putra putri, koperasi dapur hingga laundry. Untuk tahun 2019, Darul Amin terpilih menjadi pilot proyek salah satu dari 20 pesantren se-Provinsi Aceh untuk usaha Dayah Maret.

Dari tahap-tahap perkembangan tersebut, capacity building dilakukan dengan strategi yang berbeda-beda antara kelompok satuan pendidikan satu dengan satuan pendidikan lainnya. Strategi tersebut diantaranya (a) terhadap kelompok satuan pendidikan pada tahap pra-formal, strategi capacity building dilakukan umumnya melalui upaya melengkapi satuan-satuan pendidikan dengan sarana-prasarana pendidikan sesuai dengan kebutuhan mereka secara minimal tetapi memadai untuk dapat mencapai tahap perkembangan berikutnya; (b) terhadap kelompok satuan pendidikan yang sudah mencapai standar teknis (tahap formal), strategi capacity building dilakukan melalui pelatihan-pelatihan dan pengembangan kemampuan tenaga kependidikan, seperti kepala sekolah agar mampu mendayagunakan sumber-sumber pendidikan secara optimal dengan tanpa banyak pemborosan. Bagi tenaga pengajar dikembangkan kemampuan mereka untuk dapat melaksanakan proses pembelajaran secara kreatif dan inovatif, 
serta dapat melakukan penelitian terhadap pendekatan pembelaj aran yang paling efektif. Jika satuan-satuan pendidikan sudah mencapai kemampuan ini, mereka dapat ditingkatkan ke tahap perkembangan berikutnya, yaitu tahap transisional; (c) terhadap satuan-satuan pendidikan yang sudah mencapai tahap transisional, perlu dikembangkan sistem manajemen berbasis sekolah yang didukung oleh partisipasi masyarakat dalam pendidikan serta mekanisme akuntabilitas pendidikan melalui fungsi Komite Sekolah. Jika manajemen berbasis sekolah, partisipasi masyarakat dan akuntabilitas pendidikan dapat dikembangkan, maka satuan-satuan pendidikan sudah dapat dinaikan kelasnya ke Tahap Otonom.

Strategi yang sangat mendasar dalam capacity building adalah pengembangan sistem indikator yang dapat mengukur ketercapaian standar teknis dan standar pelayanan minimal di setiap satuan pendidikan. Sistem indikator ini perlu didulqmg oleh sistem pendataan pendidikan yang akurat, relevan, lengkap dan tepat waktu agar setiap saat dapat diukur dilakukan monitoring terhadap tahap perkembangan yang sudah dicapai oleh masingmasing satuan pendidikan. Sistem pendataan ini harus dilakukan sejak tingkat satuan pendidikan, kecamatan, kabupaten/ kota, propinsi sampai dengan tingkat nasional.

\section{Upaya Peningkatan Capacity Building}

Upaya pengembangan kapasitas dilaksanakan dalam berbagai tingkatan yang dapat dikemukakan bahwa pengembangan kapasitas harus dilaksanakan secara efektif dan berkesinambungan pada 3 (tiga) tingkatan-tingkatan. Pertama, tingkatan sistem, seperti kerangka kerja yang berhubungan dengan pengaturan, kebijakan-kebijakan dan kondisi dasar yang mendukung pencapaian obyektivitas kebijakan tertentu (Education, 2007). Kedua, tingkatan organisasi seperti struktur organisasi, proses pengambilan keputusan di dalam organisasi, prosedur dan mekanisme pekerjaan, pengaturan sarana dan prasarana, hubungan dan jaringan organisasi (Gibson, 2011). Ketiga, tingkatan individual, seperti keterampilan-keterampilan individu dan persyaratan-persyaratan, pengetahuan, tingkah laku, pengelompokan pekerjaan dan motivasi-motivasi dari pekerjaan orang-orang di dalam organisasi-organisasi (Kondalkar, 2007). 
Proses pengembangan kapasitas dilakukan dengan berbagai cara dan juga mencakup berbagai macam aspek, bilamana merujuk pada tingkatan tersebut diatas, maka upaya pengembangan kapasitas dilakukan pada tingkatan system, terutama dilakukan baik melalui pengembangan kebijakan, peraturan (regulasi dan deregulasi) agar sistem yang ada dapat berjalan secara efektif dan efisien untuk menjamin tercapainya tujuan individu maupun organisasi tersebut.

Pada tingkatan organisasi, secara umum dilakukan dengan pengembangan aturan main organisasi, sistem kepemimpinan, sistem manajemen, pengembangan sumberdaya manusia, serta pengembangan jaringan organisasi. Pada tingkatanindividual, secara umum dilakukan dengan pendidikan, pengajaran dan pembelajaran secara luas kepada individu itu sendiri dengan berbagai macam metode baik metode pendidikan dengan pendekatan pedagogi maupun dengan pendekat andagogi. Tidak hanya dilakukan melalui pendidikan formal tetapi juga melalui nonformal seperti kursuskursus, pelatihan, magang, sosialisasi dan lain lain.

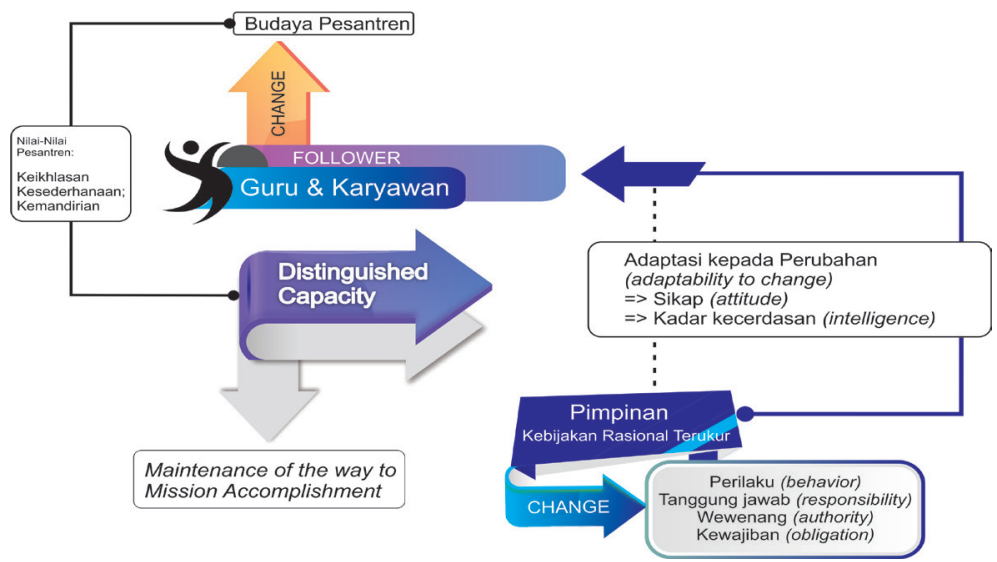

Gambar 4. Pelaksanaan Capacity Building pada Organisasi Pesantren Darul Amin

Pada gambar 4 di atas menerangkan proses pelaksanaan capacity building pada Dayah Perbatasan Darul Amin. Capacity building dimana landasan pimpinan dalam menentukan kebijakan adalah demi tercapainya visi dan misi pesantren. Mengatasi inkonsistensi proses dan juga sebagai adaptasi organisasi terhadap 
perubahan menuntut sikap yang tertuang dalam langkah konkrit berupa peningkatan kapasitas. Pimpinan sebagai manajer menuntut perubahan yang kemudian tercermin dalam bentuk perilaku, tanggungjawab, wewenang dan kewajiban. Sumber daya yang dimiliki pesantren termasuk cukup dalam pelaksanaan capacity building, sehingga pada prakteknya bawahan (guru dan karyawan) cukup mengikuti sistem yang dibentuk atas kesepakatan bersama.

Peran sentral pimpinan dalam proses pelaksanaan program sangat krusial. Kebijakan yang diterapkan pimpinan bersifat rasional dan terukur. Dalam kasus ini, seperti pembangunan sarpras unit usaha pesantren, dilakukan tanpa rencana dan berpotensi menciptakan defisit keuangan. Akan tetapi, setelah beroperasi beberapa bulan dana investasi berhasil kembali dan mendatangkan keuntungan.

Prinsip capacity building Dayah Perbatasan Darul Amin mengandung unsur partisipasi, pengulangan, relevansi, pengalihan, dan umpan balik. Dalam proses capacity building terdiri dari empat tahapan yaitu tahap (1) pra-formal (organisasi pendidikan rintisan); (2) tahap formal (organisasi pendidikan potensi); (3) tahap transisional (organisasi pendidikan standar nasional); dan (4) tahap otonom (organisasi pendidikan standar internasional). Menuju kepada eksistensi kelembagaan Darul Amin juga melakukan berbagai upaya dalam berbagai tingkatan yaitu tingkatan sistem, tingkatan organisasi dan tingkatan individual.

Selain daripada itu, filosofi budaya organisasi dalam nilai keikhlasan juga telah tertanam pada guru-guru dan karyawan di Dayah Perbatasan Darul Amin. Konsep nilai keikhlasan yang tertanam adalah berbuatlah ikhlas dan jangan mengharap untuk dicontoh, karena itu berarti tidak ikhlas tetapi show. Perbedaan karakter individu guru dan karyawan bernilai potensial, mencermati hal itu pimpinan membuat sistem guna memfasilitasi guru dalam meningkatkan kapasitas.

Unsur fundamental dalam implementasi capacity building adalah unsur partisipasi karena melibatkan seluruh komponen mulai manajemen puncak hingga manajemen operasional. Prinsip pengulangan berarti proses pengembangan terintegrasi ke dalam sistem proses pendidikan dan pengajaran pesantren. Prinsip relevansi 
dimana eksistensi pesantren adalah dengan peningkatkan mutu dan layanan dalam menghadapi tuntutan masyarakat. Sementara berkaitan dengan prinsip pengalihan, pesantren membangun relasi kerjasama stakeholder dan pesantren besar. Progres kemajuan sebagai bentuk umpan balik terhadap usaha peningkatan kelembagaan dari jumlah murid maupun prestasi. Penelitian ini selaras dengan penelitian yang dilakukan Lidstone, DeChano-Cook (2004) dan (Prasetyo, 2016).

Dalam upaya peningkatan kualitas, Darul Amin masih memerlukan perbaikan dan pengembangan pesantren dengan langkah-langkah implementasi kebijakan dalam membangun kapasitas. Upaya peningkatan pengelolaan pendidikan dengan penerapan peningkatan mutu berkelanjutan semakin menjadikan Darul Amin sebagai destinasi potensial masyarakat dalam hal pendidikan Islam.

\section{Kesimpulan}

Capacity building dalam penelitian ini mencangkup peningkatan kelembagaan. Secara definitif capacity building adalah suatu serangkaian strategi yang tertuang dalam proses untuk meningkatkan kemampuan seseorang, organisasi, atau sistem untuk meningkatkan efisiensi dan efektivitasnya. Pemenuhan aspek struktur organisasi mulai dari formalisasi, sentralisasi, kompleksitas menjadi unsur koheren dalam pengembangan kapasitas memusatkan perhatian pada tiga hal. Pertama, dimensi pengembangan SDM mencangkup langkah strategis berupa rekrutmen guru senior untuk ditempatkan pada posisi strategis pengasuhan santri dan ADM kesekretariatan, rekrutmen guru pengabdian sebagai manajer operasional lapangan menangani kegiatan ekstrakurikuler dan penanaman lifeskill santri; Kedua, dimensi penguatan organisasi mencangkup penguatan unit usaha pesantren menuju pada kemandirian ekonomi, penguatan relasi untuk meningkatkan kompetensi manajerial dan akademik guru dan menjadi salah satu sekolah penerima program SMP Berbasis Pesantren; Dimensi Ketiga, reformasi kelembagaan mencangkup perubahan status kelembagaan menjadi binaan pemerintah dan perubahan jenjang pendidikan formal. Dalam proses capacity building terdiri dari empat tahapan yaitu tahap (1) pra-formal (organisasi pendidikan rintisan); (2) tahap formal (organisasi pendidikan potensi); (3) tahap transisional (organisasi 
pendidikan standar nasional); dan (4) tahap otonom (organisasi pendidikan standar internasional). Menuju kepada eksistensi kelembagaan Darul Amin juga melakukan berbagai upaya dalam berbagai tingkatan yaitu tingkatan sistem, tingkatan organisasi dan tingkatan individual.

\section{Daftar Pustaka}

Alma, H., \& Lambert, L. (2006). Building Leadership Capacity for School. London: Open University Press. London: McGraw-Hill Education.

Bashori, Prasetyo, M. A. M., \& Susanto, E. (2020). Change Management Transformation in Islamic Education of Indonesia. Social Work and Educationducation, 7(1), 72-86. https://doi. org/10.25128/2520-6230.20.1.7.UD

Bungin, M. B. (2018). Penelitian Kualitatif, Komunikasi, Ekonomi, Kebijakan Publik, dan Ilmu Sosial Lainnya, Edisi Kedua. Jakarta: Kencana Prenada Media Grup.

Cosner, S. (2009). Building Organizational Capacity through Trust. Educational Administration Quarterly. https://doi. org/10.1177/0013161X08330502

Cresswell, J. W. (2008). Educational Research, Planning, Conducting, and Evaluating Quantitative and Qualitative Research. United States of America: Pearson Merrill Prentice Hall.

Dinas Pendidikan Dayah Aceh. (2019). Rencana Kerja Dinas Dayah 2019. Banda Aceh.

Education, O. M. O. (2007). Capacity Building Series: Student Self Assessment. In Literacy and Numeracy Secretariat Capacity Building Series.

Galamba, Kirsten, \& Nielsen, S. (2019). Capacity building in FM organisations. 6, 132-137. https://doi.org/9780367028725

Gandara, R. (2008). Capacity Building Dosen pada Jurusan di Perguruan Tinggi Badan Hukum Miliki Negara. Bandung: Fakultas Ilmu Pendidikan UPI. 
Gibson, J. L. (2011). Organizations; Behavior, Structure, Processes. (14th Editi). Singapore: Mc Graw-Hill lnternational, Inc.

Grindle, M. S. (2007). Getting Good Government, Capacity Building in the Public Sector of Developing Countries. Boston: Harper Collins Publishers.

Hadfield, M., Chapman, C., Curryer, I., \& Barrett, P. (2004). Building Capacity Developing Your School. Retrieved from http:// www.ncsl.org.uk

Harjanto, I. (2006). Pembangunan Kapasitas Lokal (Local Capacity Building). Malang: Universitas Brawijaya.

Ho, C. (2019). Capacity Building: Continuity and Change. Asian Bioethics Review, 11(1-2). Retrieved from 10.1007/s41649019-00108-Z

https://dpd.acehprov.go.id/. (2019). Profil Dayah Perbatasan Aceh. Retrieved from Dinas Pendidikan Dayah Aceh website: https:// dpd.acehprov.go.id/index.php/jelajah/read/2017/02/07/147/ profil-dayah-perbatasan-darul-amin.html

Human Development Report 2019. (2019). Inequalities in Human Development in the 21st Century, Indonesia's HDI Value and Rank. Retrieved from http://hdr.undp.org/en/countries/ profiles/IDN

Karunasena, G. (2007). Capacity Building towards Sustainability : Context of Post Disaster Waste Management.

Keban, Y. T. (1999). Capacity Building sebagai prakondisi dan Langkah Strategis Bagi Perwujudan Otonomi Daerah di Indonesia. Jurnal Kebijakan Dan Adminitrasi Publik (JKAP).

Kondalkar, V. G. (2007). Organizational Behaviour (1st ed.). New Delhi: New Age Publisher.

Ku, H. B., \& Yuen-Tsang, A. W. K. (2011). Capacity Building. In The SAGE Handbook of Governance. https://doi. org/10.4135/9781446200964.n30

Lidstone, J., Stoltman, J., \& DeChano-Cook, L. (2004). Capacity Building, Education, and Technical Training. https://doi. 
org/10.1007/978-1-4020-2851-9_27

Lincoln, Y. S., \& Guba, E. G. (2003). Turning Points in Qualitative Research. Tying Knots in a Handkerchief,, The Failure of Positivist Science. (Y. Lincoln \& N. Denzi, Eds.). California: Walnut Creek, AltaMira Press.

Matachi, A. (2006). Capacity Building Framework. UNESCO International Institute for Capacity Building in Africa.

Moleong, L. J. (2011). Metodologi Penelitian Kualitatif: Edisi Revisi. Bandung: Remaja Rosda Karya.

Mukhtar, Risnita, \& Prasetyo, M. A. M. (2020). The Influence of Transformational Leadership, Interpersonal Communication, and Organizational Conflict On Organizational Effectiveness. International Journal of Educational International Journal of Educational Review, 1(2).

Murray, J., Jones, M., McNamara, O., \& Stanley, G. (2009). Capacity $=$ Expertise $\mathrm{x}$ Motivation $\mathrm{x}$ Opportunities: Factors in Capacity Building in Teacher Education in England. Journal of Education for Teaching, 35(4), 391-408. https://doi. org/10.1080/02607470903220455

O’Brien, K., Reams, J., Caspari, A., Dugmore, A., Faghihimani, M., Fazey, I., ... Winiwarter, V. (2013). You Say You want a Revolution? Transforming Education and Capacity Building in Response to Global Change. Environmental Science and Policy, 28, 48-59. https://doi.org/10.1016/j.envsci.2012.11.011

Prasetyo, M. A. M. (2016). The Relationship between Kyai Managerial Competence, the Management Based Islamic Boarding School (MBIBS), and the Educator's Performance in Islamic Islamic Boarding School: Approach Concept. In The First International Conference on Law, Economics and Education Muhammadiyah University of Metro, Indonesia ISBN.

Rivai, V., Kamal, H., \& Muhammad, N. (2014). The Economic Of Education, Mengelola Pendidikan Secara Profesional Untuk Meraih Mutu dengan Pendekatan Bisnis (1st ed.). Jakarta: Gramedia Pustaka Utama. 
Rivai, V., \& Murni, S. (2009). Education Management. Analisis Teori dan Praktek. Jakarta: Raja Grafindo Persada.

Riyadi, S. (2010). Pengembangan Kapasitas Pemerintah Daerah Menuju Good Governance. (The Capacity Building for Local Government Toward Good Governance). Kendari.

Spoth, R., Greenberg, M., Bierman, K., \& Redmond, C. (2004). PROSPER community-university partnership model for public education systems: Capacity-building for evidence-based, competence-building prevention. Prevention Science, 5(1), 31-39. https://doi.org/10.1023/B:PREV.0000013979.52796.8b

Stoll, L. (2009). Capacity Building for School Improvement or Creating Capacity for Learning? A Changing Landscape. London: Springer Science Business Media B.V.

Stringer, P. (2013). Capacity Building for School Improvement. Rotterdam: Sense Publisher.

Tim Peneliti STIA LAN. (2012). Capacity Building Birokrasi Pemerintah Daerah Kabupaten/Kota di Indonesia. Makassar: STIA LAN.

www.dayahperbatasandarulamin.ac.id. (2019). Berita Pesantren. Retrieved from http://www.dayahperbatasandarulamin.ac.id/ 